\title{
Attitudinal Perspectives: A Factor to Implementation of a Dual Language Program
}

\section{Michael Whitacre}

Assoc. Prof., University of Texas Pan American, U.S.A. mwhitacre@utpa.edu

The central focus of this study was to determine the overall perceptions of school administrators, and the district bilingual coordinator on transferring theory to classroom practice, implementation, as viewed by those involved in the implementation process of the Gómez and Gómez Model of Dual Language Education. Responses were solicited from administrative personnel involved in the implementation of the Gómez and Gómez Model of Dual Language. Results revealed overall administrative attitudes were positive to the theoretical ideology and mixed as related to the actual implementation of the dual language program. The greatest areas of concern were; what to do when students enter the program who are either not Spanish dominant or who have not been in a dual language program. The second area of concern was with how to effectively evaluate teachers as they are observed for implementation of the dual langue program. Lastly, most administrators felt there was a lack of faculty proficient in Spanish.

Keywords: Dual language, bilingual education, one-way dual language, Gómez and Gómez model of dual language, administrative perspective

\section{INTRODUCTION}

A primary goal of bilingual education in Texas was English language development. Bilingual education could be defined as a means of using the child's first language to accelerate the acquisition of English. The expectation was that students move out of a transitional program in approximately three years and be able to function in an English only classroom. "Research and student success has revealed that three years was not a realistic time period for children to be able to master a second language" (LessowHurley, 2000, p.13). After decades of limited success with transitional early/late exit programs it became apparent that change was needed, as a result, during the late 1960's and into the early 1970's enrichment programs began to resurface. In contrast to transitional programs language enrichment or maintenance programs promoted bilingualism and biliteracy. These programs were often referred to as dual language instruction or two-way bilingual programs. This method calls for providing high quality instruction in two languages for all bilingual students (Ovando, 2003).

With a choice in programs, Texas schools have to report to the State their choice of bilingual program. Schools must make the decision of using an early or late exit 
program, or implementing a dual language program. Theoretical and philosophical perspectives influence the choice between remedial and enrichment programs. With this decision for schools, the requirement to adjust or implement a new program comes into play including change and belief in the program and its impact, all combining and contributing to its success or failure. These may include inconsistencies in program implementation, the time frame for training and implementation, inconsistencies in or a lack of training and administrative support. It is important to also consider research findings that show enrichment bilingual education allows children to reach high levels of biliteracy despite their language background when entering school (Hill, Gómez \& Gómez, 2008).

Collier and Thomas (2004) stated that it is important to have a theoretical and philosophical discussion at all levels; from parents, teachers, administrators, the general public, businesses and finally to the school board on the importance of bilingual policies, programs, and practices when changing from a remedial to an enrichment environment. The absence of these can create a lack of ownership, which often contributes to the lack of "buy in" and fidelity to implementation of the program. During implementation of dual language enrichment bilingual programs, it is important to give more focused attention to the utilization of additive linguistic and cultural strategies understanding that implementation consists of the putting into practice an idea, program, set of activities and structures new to the people attempting to implement change. Fullan (1991) also added that as a school progresses through the second year of a dual language program implementation and grade level phase-in, administrators should take time to assess and reflect upon what has been done, what has been adjusted, and what has been successful.

The need for buy-in at all levels is necessary for successful planning, implementation, and program sustainability (Freeman, Freeman, \& Mercuri, 2005; Soltero, 2004; Sugarman \& Howard, 2001; in Hill, Gómez \& Gómez, 2008). The study will be of significance to those districts or individual schools that may be investigating implementing a dual language enrichment program. The findings may serve as a guide for change from one program to another, for implementation, and for phasing in grade levels yearly. It may also serve as a comparison tool to aid in the decision making process regarding a language program that better meets the needs of a particular student population. The results identified outcomes from professional development activities, and administrators' perspectives. Literature revealed that programs supported by communities, administrators, teachers, and parents are successful and have a longer life expectancy. Administrator perspectives of a district-wide process of change from a transitional bilingual education program to a dual language enrichment education program were collected to serve as an identifier of attitudinal perspectives of change in a South Texas School District. The Gómez and Gómez Model of Dual Language Enrichment framed this study to identify effective practices from administrator perspectives for implementing a successful dual language program, and to determine if leadership was a factor in program implementation. 


\section{REVIEW OF THE LITERATURE}

\section{Effective Practices in Program Implementation}

There are many dimensions which can define the effectiveness of bilingual education such as; program goals, organization, and curriculum. It can also be measured using indicators that reflect classroom environment and instructional process and student learning (Solis, 1998). In addition, for success, a program needs supportive leadership, and should be a long-term enrichment program and not treated as a temporary compensatory program (Lindholm-Leary, 2000). Becoming change agents for implementation is one of the key factors such as the nature of the innovation, the role of the principal, and the district administrative role are associated with implementation success (Fullan, 1991).

A common factor among effective and successful school environments was the emphasis on high achievement expectations for all students and high expectations among experienced staff and new staff alike. One of the first steps in effective implementation of an identified program was to identify barriers that may hinder the programs implementation and success (Lezotte, 1991). An effective enrichment bilingual program should include vision and goals that guide the instruction communicated to the students, create well informed proactive program leaders, and clear roles and responsibilities of central staff with a strong link to the central office that creates credibility and respect for the program (Lindholm-Leary, 2000). A program is set up for failure without strong leadership. In order to be effective the combined efforts of the entire staff, school district administrators, and school board are necessary (Lezotte, 1991). Instructional leadership should reflect an atmosphere that promotes bilingualism at all levels (Lindholm-Leary, 2000).

\section{Transitional Bilingual Programs}

A primary goal of bilingual education is English language development. The academic achievement results showed that students who received transitional bilingual classes achieved at a level higher than students who received English-only instruction, where less than half the academic achievement gap was closed (Thomas \& Collier, 1998). Despite these gains there were many factors that affected its effectiveness, some included: standardized testing in English, negative perception of non-English languages and cultures, lack of consistency, limited knowledge of transfer skills from first to second language, and the belief that equality would come as soon as the students mastered English (Gomez, 2000). As stated by Lessow-Hurley (2005, p.14-15) a number of problems exist with transitional bilingual programs:

- They foster subtractive, rather than additive, bilingualism;

- They were compensatory and do not involve the monolingual English-speaking community;

- Exit assessments do not take into consideration specialized language needs and rely only on students language skills; and

- Three years was not a realistic time period for children to be able to master a second language. 
Valenzuela's book Subtractive Schooling (1999) powerfully illustrated the negative consequences of the U.S. educational system for many Mexican and Mexican American students. From her 3-year study in a Texas high school, Valenzuela concluded: the problem of achievement lies squarely in school-based relationships and organizational structures and policies designed to erase students' culture". Valenzuela stated; "I became increasingly convinced that schooling is organized in ways that subtract resources from Mexican youth" (Valenzuela, p.10). Two way bilingual program models could positively impact student's educational attainment and promote long-lasting educational and social change (Gomez, 2001). Programs that offered high-quality language exposure, academically and socially, along with multiple and creative opportunities to actively engage students in the learning process, were more effective at facilitating language acquisition than programs that did not (Ovando, 2003). According to cognitive research and theory in language acquisition, the best way for students to learn English and gain access to the high level of proficiency needed for upperintermediate and secondary instruction, was for them to attain initial mastery in their home language before addressing literacy in English (Krashen \& Biber, 1988; Willig, 1985).

\section{The Gómez and Gómez Model of Dual Language Enrichment}

Leo Gómez and Richard Gómez developed a model that was initially named the 50-50 Content Model, which was appropriate for use in areas with high numbers of English Language Learners. Originally designed and implemented in 1996, it has since undergone revisions based on initial results of campus implementation (Gómez, Freeman \& Freeman, 2005). The Gómez and Gómez Dual Language Enrichment program design does not call for instruction in each subject area in both languages. Instead, it requires that all learners at the elementary level, regardless of language background, learn certain subjects only in Language 2 (L2) and other subjects only in language 1 (L1) (Gómez, 2000). The design of the model begins at prekindergarten continuing into first grade with learners receiving language arts in their native language. Students are then heterogeneously mixed beginning in second grade; students receive their language arts instruction in both their native and their second languages. Science and social studies are taught in Spanish prekindergarten to fifth grade. Mathematics is taught in English in all grade levels to students using the same structure for grouping. (Gómez, Freeman \& Freeman, 2005).

The Gómez and Gómez model of dual language provides a 50/50 balance of both languages by content area for all grade levels of implementation (Gómez, Freeman \& Freeman, 2005). The program design also is unique in that it does not require a 50/50 mix of native English speakers and native Spanish speakers. It is important to recognize that both One-Way and Two-Way dual language enrichment programs close the achievement gap between ELL's and native English speakers (Collier \& Thomas, 2004).

In the Gómez and Gómez model students are heterogeneously grouped as well as placed in bilingual pairs or bilingual groups for all subject-area instruction. Gómez states bilingual grouping facilitates comprehension since the second language learner receives linguistic and academic support from his or her partner. Using one language for each 
subject area allows teachers to develop conceptual refinement and linguistic connections (Gómez, 2000).

Gómez, Freeman, and Freeman (2005) also stated that the model incorporates the use of bilingual learning centers and bilingual research centers. The learning centers are used in Pre-K through second and accomplished three goals: they allow students to use their L1 and L2 in natural and meaningful context; they also allow negotiation between learners of subject area meaning; and for students to engage in self-paced learning. Bilingual research centers are used in third through fifth grade and serve as subject specific reference areas to use in cooperative learning using project-based and cooperative learning activities.

\section{METHOD}

The participants in this study were involved in different stages of implementation of the Gómez and Gómez One-Way Model of Dual Language Enrichment. The study also includes the administrator's knowledge of the program components and administrative traits related to successful dual language program implementation. Qualitative data were gathered through questionnaires and interviews with administrators, principals, facilitators, and the bilingual director, using open-ended questions.

\section{Research Design}

The purpose of the study was to identify administrative perspectives in the district wide transformation process, from a transitional bilingual program to a dual language bilingual program, to include instructional leadership beliefs, experience working with bilingual students, the role of language as a factor in successful program implementation, and their perspective on professional development for program implementation. Participants were involved in different stages of implementation of the Gomez and Gomez Model of Dual Language Enrichment.

Qualitative data were gathered through questionnaires and interviews using instruments developed and tested with a sampling of dual language school administrators to establish reliability and validity. Cronbach alpha coefficient had an internal consistency of acceptable.

\section{Participant Sample}

The participants for this research study included 13 elementary school principals, 15 elementary school facilitators, the district bilingual director, and the assistant bilingual director of a south Texas school district, in the Rio Grande Valley. The schools were selected based on the following criteria:

a) That the schools were currently using The Gómez and Gómez Model of Dual Language Enrichment.

b) That the schools were in the process of implementation or in their second year of implementation or were already at the completion stage at fifth grade. 
c) That the original cohort be continuing with The Gómez and Gómez Model of Dual Language Enrichment.

\section{Data Collection}

A questionnaire to measure administrative perspectives of beliefs and effectiveness of implementation was given. Questions included indicators of effective schools and The Gómez and Gómez Model of Dual Language Enrichment. Data were collected from elementary school principals, facilitators, and or curriculum specialist and the school district bilingual director and assistant bilingual director. The questionnaires were completed on their own and returned via mail to ensure anonymity. Additionally, the Principals, Facilitators, Assistant Bilingual Director and Bilingual Director were interviewed individually in their office during their regular work hours. Questions were asked of the administrator by the researcher and responses were audio recorded and also written. Audio recordings were then transcribed and compared to written records to ensure accuracy of information.

\section{Data Analysis}

Responses to surveys and interviews were analyzed to identify patterns, emergent themes, similarities and trends among administrator perspectives of being change agents in dual language education in the district-wide process of change from transitional bilingual education to dual language education.

Data gathered from each administrator's survey and interview responses were organized by categories including; perceptions of the theoretical ideology, strategies that teachers have to implement, language issues, professional development and questions on the evaluation of implementation with fidelity to the program design. The data were analyzed, and scored to formulate generalizations. The results are presented in narrative form. The findings of the study will be used to generate recommendations regarding further study and practical applications of the results specific to the dual language program implementation.

A total of 30 administrators were issued survey questionnaires, only 20 were returned and utilized for data analysis. In addition to the questionnaires, ten face-to-face interviews were conducted with administrators and utilized in data analysis.

\section{FINDINGS}

The following are results of the data gathered. The findings validate Willig's (1985) findings that in order to have high quality programs with a high level of language and academic achievement there needs to be a favorable attitude toward bilingualism and language minority students from community, administration, and staff. Vital components to successful restructuring and implementation of enrichment models of bilingual education include: a focused and clear mission, effective teacher training, strong instructional and faculty leadership, well defined instructional practices, and a parental and community involvement plan (Gómez, 2006). The dual language model in the district was the Gómez and Gómez Model of Dual Language and was originally implemented in four elementary schools. The program starting at prekindergarten had 
since then been expanded to all 13 elementary schools within the school district. It was being implemented up to second grade in eleven of the thirteen schools. The district planned implementation up to fifth grade in all elementary schools. The overall goal of the school district was to implement the program up to high school and ultimately graduate high school students who are literate in all four-language skill areas in both English and Spanish languages.

Lead supervision, administration, and implementation of the program have been charged to the district bilingual director who reports directly back to the superintendent and to the campus principals. The director oversaw curriculum alignment, scheduling and implementing professional development for all personnel working with the program. She also conducted regular meetings with faculty and administrators, as well as also observed teachers and classroom instruction to insure that the program was implemented as designed.

Administrator perspectives responses revealed that 19 of the 20 administrators strongly agree that dual language provides a clear advantage to achieving high academic levels of achievement. Additionally, 15 of the 20 administrators strongly agreed that when implemented correctly Dual Language programs are superior to English Immersion programs. Once again a majority of the administrators 16 of the 20 believed that there was coherence and continuity in the program design.

All administrators that responded viewed the leadership role as key to the successful implementation of the program. Data revealed that all administrators believed that buyin to the program, follow through in implementation, professional development for administrators, faculty, and parents are key components that were crucial to the success of the program. However, there are some administrators that although they believed in and agreed with the dual language philosophy, found there were components of the dual language program in place that they did not agree with and in some cases altered or did not implement those components at their campuses thus altering the design and fidelity of implementation to the program model.

These components included not using bilingual pairs, bilingual learning centers as well as not teaching Science and Social Studies in Spanish. Justifications for these modifications included; many of the students are tested in English, it is difficult for teachers to teach Science and Social Studies in Spanish since they are weak in the academic language. These changes started a break down in the program and were revealed through interviews with principals who stated that some of their peers gave it "lip service" and say they are implementing the model as intended but actually were not implementing the program as designed.

The following are snippets of comments directly from Administrators, the individual questionnaires and interviews are as stated by the Administrator.

Administrator \#1 "the professional development they received had been adequate more training on implementation and appropriate follow-ups for further clarifications and questions would be beneficial. Additionally, she saw a need for more professional development in Spanish with an emphasis on training in Spanish materials to overcome

International Journal of Instruction, January $2015 \bullet$ Vol.8, No.1 
obstacles to successful implementation. Another weakness she saw is that teachers needed to develop higher proficiency levels in Spanish".

Administrator \#2 "In her opinion professional development had a huge impact on the success of implementation and that it needs to be more in-depth and ongoing. The training they received, as Administrators only included one day on theory and one day on what the model should look like in the classroom. Teachers received three day training".

"Even though she felt that the professional development they received had been adequate she felt that it is not of benefit to her. She found the theoretical portion is of the least benefit and that it is boring".

Administrator \#3 "In her opinion "professional development is essential in the implementation process". Although some training is available not everyone is able to attend due to time constraints. She felt that the professional development they received had been adequate. Despite this she believed that teachers were unqualified to teach in a dual language classroom and that teachers needed to develop a higher level of proficiency in Spanish and would like to have seen more professional development in Spanish".

Administrator \#4 her opinion of the role of an instructional leader is, "the instructional leader is the main factor of a successful dual language program and that if the leader believes and supports the staff the students and staff will be successful". She stated that if the program is followed consistently the child would be successful in both languages. She also noted that there is a lack of central office support stating, "One of the greatest obstacles to program implementation had been convincing the parents of the importance of the child learning their first language, so that their child would be successful in both languages". She also saw the need for parent training as a major deficiency of the current dual language program.

Administrators also stated that the observation component was weak. They did not feel prepared to objectively observe their teachers as they implemented components of the Gómez and Gómez model of dual language. Responses revealed that they believed that the lack of district professional development played a key role in the theory development and buy in of the program. While the professional development provided the key strategies to implementation in the classrooms they stated that ongoing professional development was inadequate in the evaluation of the program; it also lacked ongoing clinical observation and follow up.

Additionally, they also saw a need for fully training newcomer teachers. These teachers generally did not get the theoretical or pedagogical training and had to rely on their grade level peers or other trained teachers in other grade levels. Many principals stated that they relied on peer mentoring to train new teachers or as they implemented additional grades. Also identified by 16 of the 20 administrators surveyed, another factor to implementation and fidelity to the model was the lack of faculty proficient in Spanish. They expressed this as one of the greatest obstacles that have to overcome when staffing their campuses, as the pool of Spanish proficient teachers was limited. These administrators also said academic language proficiency was an obstacle to 
implementation for classroom teachers already in the classroom. Administrators stated that the teacher academic language is weak, especially in math and science. They also believe that it is important for teachers to be proficient in the language they are teaching in, as they need to be strong role models of oral language for the students. In addition to oral language modeling, correct vocabulary in Spanish is important to creating fluent language learners in the four skill areas. Some campuses had taken the self-initiative to contract additional professional development in Spanish or to hire teachers there were proficient in Spanish but this was not enough or happening in a timely manner as perceived by the administrators.

Surveys also indicated that most of the administrators at the central office and campus level are new to their positions. Statements made by participants revealed that this was due to a decision to leave by administrators who were not willing to follow the Dual language program. Data revealed that five of the eight campus principals that responded had less than five years of experience as a campus principal; of those five principals three had three years or less of experience as a principal. Eight of the 20 administrators had five or fewer years of teaching experience. Four of the 20 administrators were not bilingual/ESL certified but of those four, three had taught in bilingual classrooms. The remaining 13 of the 20 administrators had taught in a bilingual classroom. The Bilingual Director did not respond to these questions therefore the above-mentioned data does not include any data on the bilingual director. Data also revealed that 14 of the 20 respondents were bilingual or ESL Certified and 13 of them had taught in a bilingual classroom while 6 were not bilingual ESL certified and 3 had not taught in a bilingual classroom. This information implies that the majority of administrators are then knowledgeable in the theory and implementation of traditional bilingual instruction and the needs of ELL's.

Lastly, the most influential factor a majority of the respondents had was that they believed the program was not there to stay and that it would be gone soon the way other programs had come and gone.

\section{CONCLUSION}

Upon analysis of data the responses of the dual language program administrators at the selected schools, the following conclusions were made: Although the school district is in its' third year of implementation there is still not $100 \%$ commitment to the model on some campuses. Despite changes in campus administration in most schools within the last two years, it appears that new and existing Principals were not completely on board with the one-way dual language model implementation. Findings indicated that administrators believe that central office, campus administrative support, and belief in the program are instrumental to successful implementation. Responses indicated most administrators experience a slow to minimal trickle-down effect of these attitudes at all levels; from central office, campus administrators, faculty, parents and ultimately to the students. Although the overwhelming majority agreed that there is sufficient central office support, there is still a lack of communication between central office administrators as to the expectations of the students, program philosophies, implementation and integration with other programs or initiatives within the district.

International Journal of Instruction, January $2015 \bullet$ Vol.8, No.1 
Overall attitudes to the program appeared positive, with the exception of schools where there is a dominant English population of students. In those schools, administration and staff are not in agreement as to the success of the program, staff in those schools see the program as a hindrance rather than a positive due to their English dominant population struggling with acceptance and with student buy in. Spanish language instruction is the greatest obstacle that administrators feel is the hardest to overcome. An over whelming majority of administrators saw a need for teachers with better Spanish language skills and thought that more professional development in Spanish would benefit teachers.

Data reveal that campus administrators rely heavily on central office administration for direction and professional development. There was also a concern as to what to do with those students who come into the program mid-stream and have not been in a dual language program before, or have not started the dual language program in pre kinder or kinder and have missed foundational strategies. Administrators had not been trained on what to do in this situation, not taking the initiative to problem solve and provide needed resources as an effective administrator should, as indicated by Correlates of Effective Schools (Lezotte, 1991).

The author recommends that the district and the program trainers need to consider creating or identifying model classrooms or designate classrooms implementing The Gómez and Gómez Model of Dual Language Enrichment within neighboring school districts for teachers and administrators to observe. These classrooms could facilitate school district administrators and program trainers in providing campus administrators with training and ideas on what to expect in an effective dual language classroom while conducting observations. As an added measure of reliability the district might consider establishing clinical observations with recommendations from outside sources to evaluate the implementation level and the effectiveness of the program. As an integral component, training on how to integrate students coming from other campuses or for children that have not been in the dual language program beginning at pre-kinder or kinder should be included for both administrators and teachers.

With change comes doubt, but as educational policies demand more and more accountability and success for our children, school district administrators need to consider that change does not occur immediately. The importance of relying on research proven programs and fidelity to the model are key elements to achieving success in implementation. In order to see results their needs to be fidelity to the program design, implementation and time allowed for the program to flourish. The importance of relying on research proven programs and fidelity to the model are key elements to achieving success in implementation.

\section{REFERENCES}

Collier, V. P. (1989). How Long? A synthesis of research on academic achievement in a second language. TESOL Quarterly, 23(3), 509.

Collier, V.P., \& Thomas, W.P. (2004). The outstanding effectiveness of dual language education for all. NABE Journal of Research and Practice, 2(1), 1-20.

Fullan, M. (1999). Change forces: the sequel. London: Falmer Press. 
Fullan, M.G. (1991). The new meaning of educational change. School Effectiveness and School Improvement, 2(4), 336-343.

Gómez, L., Freeman, D., \& Freeman, Y. (2010). Dual language education: A promising 50-50 model. Bilingual Research Journal, 29(10), 145-164.

Gómez, L. (2000). Two-way bilingual education: Promoting educational and social change. The Journal of the Texas Association for Bilingual Education, 5(1), 43-54.

Hill,S., Gómez, R., Gomez, L. (2008). What a difference a year makes: A large urban school district's transformation from remedial to an enrichment dual language education.The Journal of the Texas Association for Bilingual Education, 10(1), 154177.

Krashen, S. \& Biber, D. (1988). On course: Bilingual education's success in California. Ontario, CA: California Association for Bilingual Education.

Lessow-Hurley, J. (2009). The foundations of dual language instruction. New York, NY: Longman. (pp. 14-15).

Lessow-Hurley, J. (2000). The foundations of dual language instruction. New York, NY: Longman.

Lindholm-Leary, K. (2000). Dual language education. Clevedon, England: Multilingual Matters.

Lezotte, L. (2001). Revolutionary and evolutionary: The effective schools movement. Okemos, MI: Effective Schools Products, Ltd.

Lezotte, L. (1991). Correlates of effective schools: The first and second generation. Okemos, MI: Effective Schools Products, Ltd.

Ovando C.J. (2003) Bilingual education in the United States: Historical development and current issues. Bilingual Research Journal: The Journal of the National Association for Bilingual Education, 27(1), 1-24. Retrieved May 21, 2012, from http://dx.doi.org/10.1080/15235882.2003.10162589

Solis, A. (1998). Showcasing exemplary instructional practices in bilingual and ESL classrooms. Retrieved June 23, 2006, from http://www.idra.org/newslttr/1998/Jan/Adela.htm.

Solis, A., \& Villarreal A. (January 1998). Effective implementation of bilingual programs: Reflections from the field. Retrieved June 23, 2006 from http://www.idra.org/newslttr/1998/Jan/Lalo.htm.

Valenzuela, A. (1999). Subtractive schooling U.S.-Mexican youth and the politics of caring. Albany: State University of New York Press.

Willig, A. C. (1985). A meta-analysis of selected studies on the effectiveness of bilingual education. Review of Educational Research, 55(3), 269-317.

\section{Turkish Abstract}

Tutumsal Perspektif: Çift Dil Programı Uygulamasında Bir Faktör

Bu çalışmanın odak noktası Gómez ve Gómez Modeli Çift Dil Eğitim programının uygulama aşamasına katılan okul yöneticilerinin ve çift dil eğitim koordinatörlerinin teoriyi sınıf içi uygulamalara aktarma konusundaki genel algılarını belirlemektir. Cevaplar Gómez ve Gómez 
Modeli Çift Dil Eğitim programının uygulamasına katılan yönetici personelden alınmıştır. Sonuçlar yönetici personelin teorik ideolojiye olumlu bir tutumunu gösterirken, çift dil eğitim programına karşı karmaşık bir tutumunu ortaya çıkarmıştır. Araştırmada en önemli nokta İspanyolcası daha iyi olmayan ya da daha önce çift dil eğitim programına katılmayan öğrenciler programa katılınca ne yapılacağıdır. İkinci önemli nokta ise çift dil eğitim programının uygulamasında öğretmenler gözlemlenirken etkili bir şekilde nasıl değerlendirileceğidir Son olarak, birçok yönetici İspanyolca'yı yeterliği olan öğretmenlerin az olduğunu belirtmişlerdir.

Anahtar Kelime: Çift Dil, Çift Dilli Eğitim, Gómez ve Gómez Modeli Çift Dil Eğitimi, Yönetici Perspektifi

\section{French Abstract}

Perspectives D'attitude : un Facteur à Mise en œuvre d'un Programme de Langue Double

Le foyer central de cette étude devait déterminer les perceptions globales d'administrateurs scolaires et le quartier le coordinateur bilingue en transfert de la théorie à la pratique de salle de classe, la mise en œuvre, çömme considéré par ceux impliqués dans le processus de mise en œuvre du G ómez et G ómez le Modèle d'Enseignement de Langue Double. On a sollicité près de réponses du personnel administratif impliqué dans la mise en œuvre du G ómez et Gómez le Modèle de Langue Double. Les résultats ont révélé que des attitudes en général administratives étaient positives à l'idéologie théorique et se sont mélangées comme lié à la mise en œuvre réelle du programme de langue double. Les domaines les plus grandes de préoccupation étaient; que faire quand les étudiants entrent dans le programme qui n'est pas l'espagnol dominant ou qui n'ont pas été dans un programme de langue double. La deuxième domaine de préoccupation était avec la façon d'efficacement évaluer des professeurs comme ils sont observés pour la mise en œuvre du programme de langue double. Finalement, la plupart des administrateurs ont estimé qu'il y avait un manque de faculté compétente en espagnol.

Mots-clés : Langue Double, Enseignement Bilingue, Langue Double À sens unique, Gó mez et Gómez Modèle de Langue Double, Perspective Administrative

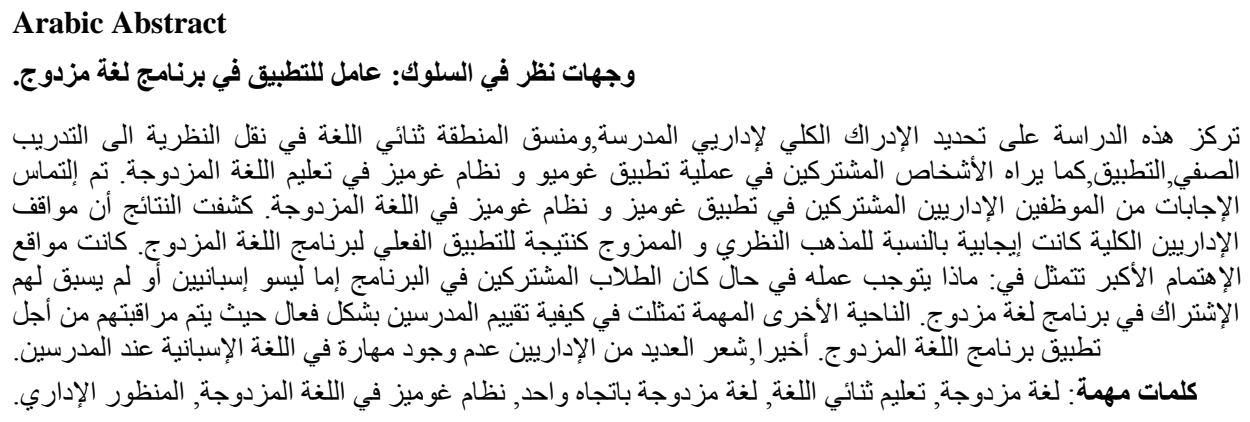

